\title{
A Quantitative Study for Evaluating Risk Factors in Routine Perioperative Assessment During Elective Bariatric Surgery Regarding the Development of Postoperative Delirium
}

\section{Anja Heymann}

Evangelisches Krankenhaus Hubertus, Berlin

\section{Martin Susewind}

Klinik für Minimalinvasive Chirurgie (MIC), Berlin

Nathalie Michelle Schneider

Evangelisches Krankenhaus Hubertus, Berlin

\section{Kevin Steffens}

Charité - University Medicine Berlin

Claudia Spies

Charité - University Medicine Berlin

Anne Pohrt

Charité - University Medicine Berlin

Anika Mueller ( $\square$ anika.mueller@charite.de)

Charité - University Medicine Berlin

\section{Research Article}

Keywords: postoperative delirium, bariatric surgery, Obstructive Sleep Apnea, BUN, Hematocrit

Posted Date: August 17th, 2021

DOI: https://doi.org/10.21203/rs.3.rs-640484/v1

License: (a) (i) This work is licensed under a Creative Commons Attribution 4.0 International License. Read Full License 


\section{Abstract}

Background: Postoperative delirium (POD) is associated with long term physical and cognitive impairment. Identification of eligible biomarkers is desirable. In this subanalysis of data collected during the prospective observational CESARO study we investigate the relevance of preoperative organ dysfunctions on the onset of POD.

Methods: $\mathrm{N}=98$ Patients undergoing laparoscopic bariatric surgery were screened for POD using the Nursing Delirium Screening Scale (Nu-DESC). All preoperative assessed routine data including laboratory results were investigated for association with the development of POD.

Results: Twenty percent of patients had POD of short duration. Obstructive Sleep Apnea (OSAS) as well as elevated BUN and low HKT were identified as predictors.

Conclusion: POD incidence was comparable to other studies nonetheless our patients had only marginal risk factors. Here identified parameters might be another piece to the answer of the question: which are correlating biomarkers to the pathophysiologic process of delirium onset?

\section{Introduction}

POD is one of the most common psychiatric diagnoses in hospital settings and can occur in context of severe illness or surgical procedures. It is an acute disturbance of attention and consciousness, associated with impairment of cognitive functions. Severity of symptoms may be subject to circadian variations (1). According to ICD-10 (F05.), there may also be disorders of circadian rhythm, psychomotor function and emotional disorders (2).

The incidence for POD depends on various factors, namely predisposing and precipitating factors. Predisposing factors include age, gender, number of comorbidities and preexisting cognitive impairments. Precipitating factors include type of surgery, deviating laboratory results and medication.

POD causes prolongation of ventilation, intensive care and hospital stay and increases mortality rates (3). Long-term consequences include the occurrence of posttraumatic stress disorder (4), postoperative cognitive dysfunction (5) and the onset of dementia within 5 years from surgery (6).

In previous studies, several risk factors for the development of POD have been identified. Maldonado combined previously established hypotheses into a pathophysiological network to explain development of POD. His model includes various hypotheses including inflammation, stress, oxygen deprivation, disturbance of circadian rhythmicity and degenerative changes due to biological aging and pre-existing neurological diseases (7).

The identification of further risk factors is important to develop preventive measurements as POD is associated with significant decrease for patient's overall health (8). Moreover, preventive measurements not only benefit patient's health but also save money in healthcare system $(9,10)$. 
In OECD countries, incidence of obesity is steadily increasing (11). In Germany, about $67 \%$ of men and $53 \%$ of women aged 18 to 79 years are overweight $(\mathrm{BMI} \geq 25 \mathrm{~kg} / \mathrm{m} 2)$ and about a quarter of adults are obese (BMI $\geq 30 \mathrm{~kg} / \mathrm{m} 2)$. Four percent of men and three percent of women even suffer from obesity grade III (BMI $\geq 40 \mathrm{~kg} / \mathrm{m} 2$ ) (12). Due to this development, an increased incidence of comorbidities which are associated with obesity can be observed (arterial hypertension, type 2 diabetes, obstructive sleep apnea syndrome, depression, an increased level of inflammation, etc.) $(13,14)$.

There are only a few studies that examine the relationship between bariatric surgery and typical risk factors for POD specifically in this population. Invasive surgery is mainly performed in patients with obesity grade III (BMI $\geq 40 \mathrm{~kg} / \mathrm{m} 2$ ), but sometimes already used in obesity grade II patients (BMI 35-39.9 $\mathrm{kg} / \mathrm{m} 2)$.

To assess the risk for POD in the setting of bariatric surgery, we aim to investigate whether risk factors for the development of POD can be evaluated in routine preoperative patient assessment to derive future preventive measures.

The present study is a subanalysis of the CESARO study (15). CESARO is a multicenter, prospective observational study examining the relationship between acetylcholinesterase activity and butyrylcholinesterase activity and the occurrence of postoperative delirium (POD). The present subanalysis examines data from the department of bariatric surgery.

In this subanalysis patients were recruited at the Berlin Clinic for Minimally Invasive Surgery (Clinic for MIC).

\section{Methods}

$\mathrm{N}=98$ patients were included into the present study. All patients underwent elective bariatric minimal invasive surgery, namely either sleeve gastrectomies or Roux-Y bypass reconstructions. Survey period was from August 1, 2015, to December 31, 2015.

The ethics vote for CESARO study was granted by the local independent ethics committee (ref. : EA1/220/13, chairman Prof. Dr R. Uebelhack) of Charité-Universitätsmedizin Berlin (NCT01964274) and written informed consent was obtained from each patient. Furthermore, all local data privacy regulations were followed.

The following conditions were determined as inclusion criteria for the present analysis: laboratory measurements have to be less than 4 weeks old; patients need to be at least 18 years old, elective general anesthesia must be followed by monitoring in the recovery room or admission to a postanesthesia care unit and patients should be hospitalized for at least $24 \mathrm{~h}$ after surgery.

Patients with already known pseudocholinesterase deficiency, patients with speech, vision or hearing disorders and patients with illiteracy or insufficient knowledge of German or English were excluded from this study. Furthermore, participation was not possible in case of unwillingness to store and share 
pseudonomized patient's data. Patients in prison or similar institutions (AMG $\S 40$ ), patients working in our study center, patients who participate in another prospective clinical intervention study or shown a RASS score lower than -2 were also excluded from this study.

Patients with diabetes mellitus received capillary blood glucose monitoring preoperatively. If capillary blood glucose limit was exceeded, insulin therapy was adjusted. For surgery, standardized general anesthesia was performed without prior premedication. For induction, $3.5 \mathrm{mg} / \mathrm{kg}$ propofol, $0.15 \mu \mathrm{g} / \mathrm{kg}$ sufentanyl, and $1.5 \mathrm{mg} / \mathrm{kg}$ succinylcholine were used. Anesthesia was maintained in balanced form using desflurane $+\mathrm{O}_{2}$ /room air mixture according to MAC with a target range of $0.8-1.2,0.05-0.15$ $\mu \mathrm{g} / \mathrm{Kg} / \mathrm{min}$ remifentanyl and relaxometry-guided rocuronium. For further analgesia, $1-2 \mathrm{~g}$ of dipypirone was used regularly. In case of more analgesia requirement, additional $0.5 \mathrm{mg} / \mathrm{kg}$ ketamine or $40 \mathrm{mg}$ parecoxib was applicated. Antiemetic prophylaxis was provided applicating 4-8 $\mathrm{mg}$ dexamethasone and $8 \mathrm{mg}$ ondansetron or $10 \mathrm{mg}$ metoclopramide. In case of relaxant overload at the end of surgery pyridostigmine and atropine were administered to antagonize muscle relaxation. Intraoperative hypotension was treated with Akrinor (Theodrenalin/Cafedrin) or norepinephrine, aiming for MAP > 65 $\mathrm{mmHg}$ and less than $20 \%$ deviation from baseline. Ventilation was pressure-controlled with positive endexpiratory pressure (PEEP) between $8-15 \mathrm{mmHg}, \mathrm{FiO}_{2} 0.4-0.7$ aiming $\mathrm{SaO}_{2}>90 \%$. Intraoperative monitoring consisted of 3-lead ECG, 3-minute Riva Rocci blood pressure measurement, continuous measurement of oxygen saturation $\left(\mathrm{SaO}_{2}\right)$, ventilation and respiratory parameters and depth of relaxation. Piritramide was titrated for postoperative pain management in the recovery room; supplemental $40 \mathrm{mg}$ parecoxib was given if analgesia was inadequate. All patients received temporary CPAP therapy in recovery room.

Preoperatively various parameters were analyzed, including baseline data, comorbidities, standard laboratory parameters and the use of various scores.

The following parameters were collected: age, gender, type and duration of surgery and anesthesia, length of stay in the recovery room, and length of stay in hospital.

Comorbidities, especially arterial hypertension, heart disease, diabetes mellitus, COPD, obstructive sleep apnea (OSAS) and depression were extracted from premedical history. Alcohol and nicotine consumption as well as any regular medication have also been documented.

All patients underwent preoperative routine laboratory tests (see Table 1). 
Table 1

routinely assessed parameters

\section{Categorie}

red blood count

\section{Specific Parameter}

Leukocytes, Erythrocyten, Hemoglobin, Hematokrit, MCV, MCH, MCHC, Thrombocytes, RDW

CRP

Coagulation parameter

Liver- und lipid metabolism parameter

Retention parameter
CRP

INR, pTT sec, Quick \%

GOT $\mu \mathrm{mol} / \mathrm{ls}$, GPT $\mu \mathrm{mol} / \mathrm{ls}, \gamma$-GT $\mu \mathrm{mol} / \mathrm{ls}$, Bili $\mu \mathrm{mol} / \mathrm{ls}$, Chol. mmol/l

endocrine Parameter

GFR $\mathrm{ml} / \mathrm{min}$, Creatinin mmol/l, BUN $\mu \mathrm{mol} / \mathrm{l}, \mathrm{BUN} /$ Crea-Quotient, uric acid $\mathrm{mmol} / \mathrm{l}$, Sodium $\mu \mathrm{mol} / \mathrm{l}$, Potassium $\mathrm{mmol} / \mathrm{l}$

TSH mU/l, Serum glucose mmol/l, HbA1c \%

Patients were categorized using the ASA risk classification, which is intended to provide information about patient's general physical condition (16). To estimate the risk for obstructive sleep apnea syndrome the STOP-BANG score was used (17). A cut-off value of $\geq 5$ is associated with a high risk of obstructive sleep apnea.

We used the Nursing Delirium Screening Scale (Nu-Desc) according to Gaudreau et al. (18) for delirium detection in recovery room. Nu-Desc is a nursing-based tool for standardized diagnosis of POD based on criteria of DSM-IV. The questionnaire asks for the following topics: disorientation, inappropriate behavior, inappropriate communication, illusions / hallucinations and psychomotoric retardation. Usually, this score is raised by nurses and the individual parts score from 0 to 2 . If the total score reaches 2 points or more, the patient has delirium.

The score was assessed three times (before starting anesthesia as baseline, 10 minutes after arrival in the recovery room and at the time leaving the recovery room).

The Richmond Agitation-Sedatation Scale (RASS) is a clinical scale to assess the individual depth of sedation and agitation. The scale ranges between +4 (violent) and -5 (comatose). RASS Score was used on arrival in the recovery room and 10 minutes later.

In order to investigate the relationship between pre-existing diseases, laboratory abnormalities and the occurrence of POD, patients with missing laboratory values were excluded from this study. Moreover, patients with RASS- Score $<-2$ could not be diagnosed with delirium, which also led to exclusion.

\section{Statistical analysis}

The statistical evaluation was performed using SPSS Statistics 23 (19). First, descriptive statistics were calculated (age, gender distribution, BMI, type of surgery, duration of surgery, duration of the AWR stay and length of hospital stay). Participants were then divided in two groups, depending on occurrence of 
POD. Afterwards, the groups were compared for differences in surveyed parameters. For Interpretations significance level of alpha $<0.05$ was chosen.

To estimate associations of these variables with the risk of POD, variables that differed significantly and marginally not significantly between groups, were included in univariate logistic regression models, where the presence of postoperative delirium according to Nu-DESC was chosen as the dependent variable.

Finally, in order to determine adjusted odds ratios and confidence intervals, the significant and marginally insignificant variables from the univariate analyses were combined in a multivariate logistic regression model. Backward elimination was carried out using likelihood method.

\section{Results}

Initial $\mathrm{N}=119$ patients were included in this study. After excluding 19 people due to technical problems and 2 because of low RASS scores, 98 patients remained in the group, including 18 men (18\%) and 80 women (82\%).

The mean age was $45.52 \pm 11.3$ years. The mean BMI was $48.38 \pm 8.46$. Forty-second patients ( $43 \%)$ underwent sleeve gastrectomy and 56 underwent Roux-en-Y gastric bypass surgery (57\%). The length of stay (LOS) in hospital was 3.96 days \pm 79 days. The time of surgery was $76 \pm 27$ minutes. Patients stayed in the recovery room for $102 \pm 34$ minutes. 
Table 2

Descriptive statistics

\begin{tabular}{|lll|}
\hline Parameter & Amount & $\begin{array}{l}\text { Mean (Standard deviation) } \\
\text { Median [IQR] }\end{array}$ \\
\hline patients & 98 & - \\
\hline male & $18(18.4 \%)$ & - \\
\hline female & $80(81.6 \%)$ & - \\
\hline age & - & $45.52(11.3)$ \\
\hline BMl & - & $45.5[37 ; 55]$ \\
\hline Sleeve Gastrectomy & $42(42.9 \%)$ & - \\
\hline Roux-en-Y-gastric-bypass & $56(57.1 \%)$ & - \\
\hline time of surgery in min & - & $76.38(8.46)$ \\
& & $72[5.55[43.18 ; 52.23]$ \\
\hline LOS recovery room & - & $102(35)$ \\
\hline LOS hospital & & $95[75 ; 120]$ \\
\hline
\end{tabular}

Since the variables did not distribute normally, group differences were calculated using Mann-Whitney-U test. Effect size was estimated with Cohen's r or Cramers Phi (20).

According to Nu-DESC scores, $n=20$ patients did show POD (20.4\%). In all cases POD disappeared before leaving the recovery room. The POD group had $10 \%$ more male patients. In addition, patients with POD shown higher mean BMI. The percentage of Roux-Y operations performed in group with POD was $10 \%$ higher than in the delirium-negative group. Patients with diabetes mellitus and / or a higher BMI received operation according to Roux-Y more often. Mann-Whitney-U test did not reveal a significant difference between groups for any of the basic characteristics mentioned (see Table 3, Sect. 1).

None of our patients reported alcohol abuse. However, patients who developed POD suffered more often from COPD, arterial hypertension and were smokers. For pre-existing diseases, we also found differences between our groups, however only OSAS + CPAP reached statistical significance level (see Table 3, Sect. 2). 
Regarding blood count, only hematocrit values were significantly lower in POD group $(p=0.03)$. Further blood parameters did not differ significantly between groups (see Table 3, Sect. 3).

BUN levels were significantly higher in POD group $(p=0.02)$. All further nephrological parameters did not show significant difference (see Table 6, Sect. 7).

Regarding CRP, the delirium-positive group had lower CRP values than the negative group. However, this difference was not statistically significant (see Table 3, Sect. 4). Coagulation parameters, metabolism parameters, and endocrine parameters did not differ significantly between groups too (see Table 3 , Sect. 5). 
Table 3

patients characteristics

\begin{tabular}{|c|c|c|c|c|}
\hline & & $\begin{array}{l}\text { Delirium } \\
\text { negative }\end{array}$ & $\begin{array}{l}\text { Delirium } \\
\text { positive }\end{array}$ & $p$ \\
\hline Section 1: & Patients & $\mathrm{n}=78(\%)$ & $\mathrm{n}=20$ & - \\
\hline \multirow[t]{9}{*}{ Basic characteristics } & Male & $n=13$ & $\mathrm{n}=5$ & \multirow[t]{2}{*}{$0,391^{\mathrm{a}}$} \\
\hline & Female & $\mathrm{n}=65$ & $\mathrm{n}=15$ & \\
\hline & Age & $M D=47$ & $M D=44$ & $0.748^{b}$ \\
\hline & BMI & $M D=46$ & $M D=49$ & $0.628^{b}$ \\
\hline & Sleeve Gastrectomy & $\mathrm{n}=35$ & $n=7$ & \multirow[t]{2}{*}{$0.426^{a}$} \\
\hline & $\begin{array}{l}\text { Roux-en-Y-gastric- } \\
\text { bypass }\end{array}$ & $n=43$ & $n=13$ & \\
\hline & Time of surgery (min) & $M D=71$ & $M D=72$ & $0.724^{b}$ \\
\hline & $\begin{array}{l}\text { LOS in recovery room } \\
(\min )\end{array}$ & $M D=96$ & $M D=90$ & $0.856^{b}$ \\
\hline & LOS in hospital (d) & $M D=4$ & $M D=4$ & $0.748^{b}$ \\
\hline \multirow{11}{*}{$\begin{array}{l}\text { Section 2: } \\
\text { Pre-existing Diseases }\end{array}$} & ASA-Score & $M D=3$ & $M D=3$ & $0.360^{\mathrm{b}}$ \\
\hline & NYHA-Score & $M D=0$ & $M D=0$ & $0.715^{\mathrm{b}}$ \\
\hline & Smoker & $\mathrm{n}=18$ & $n=6$ & $0.520^{\mathrm{a}}$ \\
\hline & Arterial hypertension & $n=46$ & $n=13$ & $0.623^{a}$ \\
\hline & $\begin{array}{l}\text { Cardiovascular } \\
\text { disease }\end{array}$ & $n=5$ & $n=1$ & $0.814^{\mathrm{a}}$ \\
\hline & COPD & $n=14$ & $n=5$ & $0.477^{\mathrm{a}}$ \\
\hline & Diabetes mellitus & $\mathrm{n}=20$ & $n=5$ & $0.953^{\mathrm{a}}$ \\
\hline & STOP-BANG $\geq 5$ & $n=36$ & $\mathrm{n}=11$ & $0.489^{a}$ \\
\hline & OSAS & $\mathrm{n}=30$ & $\mathrm{n}=10$ & $0.349^{a}$ \\
\hline & CPAP + OSAS & $\mathrm{n}=3$ & $n=4$ & $0.012^{\mathrm{a}^{*}}$ \\
\hline & Depression & $\mathrm{n}=14$ & $n=3$ & $0.756^{\mathrm{a}}$ \\
\hline
\end{tabular}

$(n)=$ Group size; $M D=$ Median, ${ }^{\mathrm{a}}=\mathrm{Chi}^{2}$ test $^{\mathrm{b}}{ }^{\mathrm{b}}=$ Mann-Whitney-U test; ${ }^{*} p<0.05$ 


\begin{tabular}{|c|c|c|c|c|}
\hline & & $\begin{array}{l}\text { Delirium } \\
\text { negative }\end{array}$ & $\begin{array}{l}\text { Delirium } \\
\text { positive }\end{array}$ & $p$ \\
\hline & $\begin{array}{l}\text { Amount of } \\
\text { comorbidities }\end{array}$ & $M D=2$ & $M D=3$ & $0.180^{\mathrm{b}}$ \\
\hline \multirow{9}{*}{$\begin{array}{l}\text { Section 3: } \\
\text { Blood count }\end{array}$} & WBC $1 \times 10^{9}$ & $M D=8.1(59)$ & $M D=8.1(13)$ & $0.826^{b}$ \\
\hline & Ery Tpt/I & $\begin{array}{l}M D=4.76 \\
(58)\end{array}$ & $\begin{array}{l}M D=4.59 \\
(13)\end{array}$ & $0.457^{b}$ \\
\hline & $\mathrm{Hb} \mathrm{mmol} / \mathrm{I}$ & $\begin{array}{l}M D=8.56 \\
(59)\end{array}$ & $M D=8.1(13)$ & $0.119^{b}$ \\
\hline & Hematocrit \% & $\begin{array}{l}M D=41.3 \\
(57)\end{array}$ & $M D=39(13)$ & $0.027^{b^{*}}$ \\
\hline & MCV fl & $M D=87(57)$ & $\begin{array}{l}M D=86.6 \\
(13)\end{array}$ & $0.994^{b}$ \\
\hline & $\mathrm{MCH}$ fmol & $M D=1.8(57)$ & $\begin{array}{l}M D=1.81 \\
(13)\end{array}$ & $0.952^{b}$ \\
\hline & $\mathrm{MCHC} \mathrm{mmol} / \mathrm{l}$ & $\begin{array}{l}M D=20.73 \\
(57)\end{array}$ & $\begin{array}{l}M D=20.6 \\
(13)\end{array}$ & $0.717^{b}$ \\
\hline & Thromb Gpt/l & $\begin{array}{l}M D=278.5 \\
(58)\end{array}$ & $M D=274(13)$ & $0.800^{\mathrm{b}}$ \\
\hline & RDW \% & $\begin{array}{l}M D=13.5 \\
(32)\end{array}$ & $M D=14(8)$ & $0.378^{b}$ \\
\hline $\begin{array}{l}\text { Section 4: } \\
\text { C-reactive protein }\end{array}$ & CRP mg/l & $M D=9(8)$ & $\begin{array}{l}M D=5.35 \\
(45)\end{array}$ & $0.099^{b}$ \\
\hline \multirow{3}{*}{$\begin{array}{l}\text { Section 5: } \\
\text { Coagulation parameters }\end{array}$} & INR & $M D=1(56)$ & $\begin{array}{l}M D=1.02 \\
(12)\end{array}$ & $0.418^{b}$ \\
\hline & pTT sec & $\begin{array}{l}M D=29.35 \\
(56)\end{array}$ & $\begin{array}{l}M D=30.15 \\
(12)\end{array}$ & $0.898^{b}$ \\
\hline & Quick \% & $M D=100$ & $M D=97(11)$ & $0.605^{b}$ \\
\hline \multirow{4}{*}{$\begin{array}{l}\text { Section 6: } \\
\text { Liver/ lipid metabolism } \\
\text { parameters }\end{array}$} & GOT $\mu \mathrm{mol} / \mathrm{ls}$ & $\begin{array}{l}M D=0.38 \\
(53)\end{array}$ & $\begin{array}{l}M D=0.43 \\
(11)\end{array}$ & $0.575^{b}$ \\
\hline & GPT $\mu \mathrm{mol} / \mathrm{ls}$ & $\begin{array}{l}M D=0.49 \\
(52)\end{array}$ & $\begin{array}{l}M D=0.59 \\
(12)\end{array}$ & $0.380^{\mathrm{b}}$ \\
\hline & $\mathrm{\gamma}$-GT $\mu \mathrm{mol} / \mathrm{ls}$ & $\begin{array}{l}M D=0.52 \\
(53)\end{array}$ & $\begin{array}{l}M D=0.85 \\
(12)\end{array}$ & $0.636^{b}$ \\
\hline & Bili $\mu \mathrm{mol} / \mathrm{ls}$ & $M D=7.57$ (8) & $M D=4.36(2)$ & $0.150^{b}$ \\
\hline
\end{tabular}




\begin{tabular}{|c|c|c|c|c|}
\hline & & $\begin{array}{l}\text { Delirium } \\
\text { negative }\end{array}$ & $\begin{array}{l}\text { Delirium } \\
\text { positive }\end{array}$ & $p$ \\
\hline & Chol. mmol/l & $\begin{array}{l}M D=5.25 \\
(10)\end{array}$ & $M D=4.11(1)$ & $0.343^{b}$ \\
\hline \multirow{7}{*}{$\begin{array}{l}\text { Section 7: } \\
\text { Urinary substances and } \\
\text { electrolytes }\end{array}$} & GFR $\mathrm{ml} / \mathrm{min}$ & $\begin{array}{l}M D=93.5 \\
(42)\end{array}$ & $\begin{array}{l}M D=89.5 \\
(10)\end{array}$ & $0.684^{b}$ \\
\hline & Creatinin mmol/l & $\begin{array}{l}M D=68.54 \\
(54)\end{array}$ & $\begin{array}{l}M D=73.07 \\
(12)\end{array}$ & $0.262^{b}$ \\
\hline & $\mathrm{BUN} \mu \mathrm{mol} / \mathrm{l}$ & $\begin{array}{l}M D=5.13 \\
(20)\end{array}$ & $M D=8.74(3)$ & $0.018^{b^{*}}$ \\
\hline & BUN/Crea-Quotient & $\begin{array}{l}M D=0.07 \\
(19)\end{array}$ & $M D=0.10(3)$ & $0.053^{b}$ \\
\hline & Uric acid mmol/l & $\begin{array}{l}M D=380.7 \\
(11)\end{array}$ & $\begin{array}{l}M D=422.34 \\
(1)\end{array}$ & $0.468^{b}$ \\
\hline & Sodium $\mu \mathrm{mol} / \mathrm{I}$ & $M D=140(55)$ & $\begin{array}{l}M D=140.2 \\
(10)\end{array}$ & $0.971^{b}$ \\
\hline & Potassium mmol/l & $\begin{array}{l}M D=4.49 \\
(54)\end{array}$ & $M D=4.5(9)$ & $0.723^{b}$ \\
\hline \multirow{3}{*}{$\begin{array}{l}\text { Section 8: } \\
\text { Endocrine parameters }\end{array}$} & $\mathrm{TSH} \mathrm{mU} / \mathrm{I}$ & $\begin{array}{l}M D=1.76 \\
(44)\end{array}$ & $M D=1.69(9)$ & $0.670^{b}$ \\
\hline & Serumglucose $\mathrm{mmol} / \mathrm{l}$ & $\begin{array}{l}M D=5.66 \\
(27)\end{array}$ & $M D=5.38(7)$ & $0.782^{b}$ \\
\hline & $\mathrm{HbA} 1 \mathrm{c} \%$ & $M D=5.6(41)$ & $M D=6.25(6)$ & $0.159^{b}$ \\
\hline
\end{tabular}

\subsubsection{Effect sizes}

Effect sizes were calculated, for parameters which differed significantly between POD and non-POD group, using Cohen's r or Cramers Phi (see table 4). The effect sizes for OSAS + CPAP and hematocrit are estimated to be weak and those of BUN to be medium (20).

Table 4

Effect sizes for parameters with significant $p$-value 


\begin{tabular}{|lllll|}
\hline & $\boldsymbol{p}$ & $\mathbf{Z}$ & $\mathbf{n}$ & Cohen's r \\
\hline OSAS + CPAP & $0.012^{*}$ & 2.49 & 98 & $0.25^{\mathrm{a}}$ \\
\hline Hematocrit & $0.027^{*}$ & 2.22 & 70 & $0.26^{\mathrm{b}}$ \\
\hline BUN & $0.018^{\star}$ & 2.37 & 23 & $0.5^{\mathrm{b}}$ \\
\hline \multicolumn{2}{|l}{ acramers Phi; b Cohen's r } & & \\
\hline
\end{tabular}

\subsection{Regression analysis}

Group comparisons using the Mann-Whitney $\mathrm{U}$ and $\mathrm{Chi}^{2}$-Test were able to provide initial indications for relevant parameters related to the occurrence of POD. The following regression models were calculated to assess their relevance in a common explanatory model.

\subsubsection{Univariate regression}

Variables that differed significantly were included in following analysis. In addition, the number of secondary diagnoses and the $\mathrm{HbA} 1 \mathrm{c}$ level were examined in univariate logistic regression, as these have shown to be reliable predictors in previous research and in our main study (15).

Among these variables only OSAS + CPAP and hematocrit (see table 5) remain as relevant predictors in the explanatory model after considering the confidence intervals.

Table 5

Univariate logistic regression

\begin{tabular}{|llll|}
\hline & $p$ & Odds-Ratio & 95\%-Confidence Interval \\
\hline Amount of secondary diagnoses & .98 & 1.289 & $0.955-1.742$ \\
\hline OSAS + CPAP & $.024^{*}$ & 6.250 & $1.273-30.688$ \\
\hline Hematocrit & $.046^{*}$ & 0.805 & $0.651-0.996$ \\
\hline BUN & .054 & 1.839 & $0.989-3.421$ \\
\hline HbA1c & .069 & 2.238 & $0.939-5.335$ \\
\hline${ }^{*} p<0.05$ & & & \\
\hline
\end{tabular}

\subsubsection{Multivariate regression}

Multivariate logistic regression was performed using likelihood method. Stepwise backward elimination (see Table 6) was performed for 70 patients ( 57 were delirium negative and 13 delirium positive). Due to hematocrit parameters that were older than 4 weeks, $n=26$ patients could not be considered in our analysis. Originally, we intended to include $\mathrm{HbA} 1 \mathrm{c}$ and $\mathrm{BUN}$ in our multivariate regression analysis but 
due to a high proportion of missing values in these variables, the available population would have been reduced to $n=12$.

Regarding odds ratios and considering the confidence intervals only hematocrit could be maintained as a relevant predictor. Adjusted for the other variables, the presence of OSAS + CPAP increased odds of POD by 5.91-fold compared with those who did not have OSAS + CPAP and a hematocrit value increased of $1 \%$ was associated with a 0.74 -fold reduction of POD odds.

Table 6

Multivariate regression analysis with backward elimination

\begin{tabular}{|lllll|}
\hline Step & Predictor & $\boldsymbol{p}$ & Odds-Ratio & 95\%-Confidence Interval \\
\hline 1 & Secondary diagnoses & 0.641 & 1.112 & $0.713-1.733$ \\
\hline & OSAS + CPAP & 0.094 & 5.089 & $0.757-34.202$ \\
\hline \multirow{2}{*}{2} & Hematocrit & 0.046 & 0.798 & $0.639-0.996$ \\
\hline & OSAS & 0.053 & 5.918 & $0.977-35.831$ \\
\hline
\end{tabular}

\section{Discussion}

Objective of this investigation was to evaluate the potential association between preexisting diseases or organ dysfunctions and the development of POD in bariatric patients. Twenty percent of the study population developed POD in the recovery room. During bariatric surgery, especially during early postoperative period, patients could be at high risk for emergence delirium. Extubation and the period thereafter carries the risk of hypoxia in obese patients because residual capacity is reduced and atelectasis is likely (21).

Obstructive Sleep Apnea (OSAS) + CPAP as well as elevated BUN and low Hematocrit were identified as predictors in group comparisons. However, after multivariate regressions and considering confidence intervals only hematocrit could be maintained as a relevant predictor. The incidence is comparable to previous studies, nevertheless it is surprising as the patients of this group were young (mean age 45.5 years) and had only few comorbidities (mean 2.6).

We found that patients with CPAP-depended OSAS had significantly higher risk for POD. A correlation between OSAS and delirium has been reported previously (22). Obesity is one of the main risk factors for OSAS (23) because of the obstructive effect and the resistance that the respiratory muscles have to overcome due to the accumulation of fat in thorax and abdomen area (24). In our population OSAS 
without CPAP therapy did not lead to a higher risk for POD, suggesting that the risk raises with the severity of OSAS.

During apnea intermittent hypoxia occurs, leading to oxidative stress. Especially neuronal tissue has only low hypoxia tolerance, resulting in apoptosis. The delirogenic effect is mainly explained by the loss of cholinergic neurons. Lately a reduction of IGF-1 was found in patients with OSAS. IGF-1 has antiinflammatoric and neuroprotective effects. As inflammation is a relevant factor in the pathophysiology of delirium, this could be relevant in the connection between OSAS and delirium (23).

Sher $(25)$ and other authors $(26,27)$ described chronic inflammation and an activated immune system in obese patients. We did not find a positive correlation between C-reactive protein levels and POD. All patients were screened for a preexisting adrenal disturbance several months prior to the operation reviewing the patient's history of cortisol levels no significances were found either (data not shown). Unfortunately, we had no extended analysis of further inflammatory markers.

There wasn't a correlation between POD and age or number of comorbidities. We could not reproduce the finding that the risk for POD rises with the BMI, which was expected, because with higher BMI the risk for OSAS and comorbidities rises $(28)$. Furthermore, Feinkohl et al. $(29,30)$ report a higher incidence of cognitive dysfunction in obese patients (BMI > 30).

Our differing results may also be due to the young age of our population. Patients with Roux-Y - bypass had $10 \%$ more POD than patients with Sleep gastrectomy. Roux-y-bypass is more invasive and more frequently performed in patients with higher BMI and more comorbidities. On the other hand, patients with extreme obesity and or multiple diseases are often scheduled for sleeve gastrectomy because of the lower surgical risk and the faster procedure, so this effect could have been counterbalanced.

Length of surgical procedure had no effect on the onset of POD, which may be due to the brevity of the minimal invasive technique.

Regarding blood tests, low hematocrit correlated with the onset of POD. The impact of anemia on delirium has been described previously (31-33). Elevated BUN and BUN/Creatinine have been confirmed as risk factors. This was published before $(34,35)$ and was lead back to dehydration or renal dysfunction. In our study, patients were on a high protein diet during the weeks prior to the operation, this may have contributed as well.

We did not find correlation between delirium and diabetes. This was unexpected as well and might be explained by a strict preoperative blood glucose control.

\section{Conclusion And Limitations}

In this investigation, we aim to evaluate the risk for POD in bariatric surgery. Despite low risk profile $20 \%$ of patients developed delirium in the recovery room. Obstructive Sleep Apnea (OSAS) + CPAP as well as elevated BUN and low Hematocrit were identified as predictors in group comparisons. After multivariate 
regressions with backward elimination and considering confidence intervals, only hematocrit could be maintained as relevant predictor. Additional to already identified predictors we did not examine further intraoperative parameters (e.g. hemodynamic, anesthesia depth, blood gas). Common risk factors such as age, BMl etc. could not be confirmed in our population and might be explained by the relatively young age, short surgical time, little medication and a low statistical power. Our findings might be another piece to answer the research question: what are correlating biomarkers to pathophysiologic process of delirium onset?

\section{Declarations}

\section{Ethics approval and consent to participate}

The ethics vote for CESARO study (EA1/220/13) was granted by ethics committee of CharitéUniversitätsmedizin Berlin (NCT01964274). Only participants who gave their consent were considered in this study.

\section{Consent for publication}

Not applicable.

\section{Availability of data and materials}

The datasets used and/or analysed during the current study are available from the corresponding author on reasonable request.

\section{Competing interests}

The authors declare that they have no competing interests.

\section{Funding}

CESARO study group received funding from Dr. Franz Köhler Chemie GmbH (Bensheim, Germany). The financial contributor had no role in study design, data collection, analysis, decision to publish or preparation of the article.

\section{Authors' contributions}

$\mathrm{AH}$ conducted the analysis and wrote the article. MS recruited patients and performed the surgery. KS collected and analyzed data. NMS contributed to data analysis and wrote the manuscript. AP supported the biometric evaluation. CS and AM designed the study and operated the project.

\section{Acknowledgements}

Not applicable. 


\section{References}

1. Falkai P, Wittchen H-U, Döpfner M, Gaebel W, Maier W, Rief W, u. a., Herausgeber. Diagnostisches und statistisches Manual psychischer Störungen DSM-5®. 2. korrigierte Auflage, deutsche Ausgabe. Göttingen: Hogrefe; 2018. 1298 S.

2. Dilling $H$, Mombour W, Schmidt MH, Schulte-Markwort E, Remschmidt $H$, Weltgesundheitsorganisation, Herausgeber. Internationale Klassifikation psychischer Störungen: ICD10 Kapitel V (F) klinisch-diagnostische Leitlinien. 10. Auflage, unter Berücksichtigung der Änderungen entsprechend ICD-10-GM 2015. Bern: Hogrefe Verlag; 2015. 449 S.

3. van den Boogaard M, Schoonhoven L, van der Hoeven JG, van Achterberg T, Pickkers P. Incidence and short-term consequences of delirium in critically ill patients: A prospective observational cohort study. Int J Nurs Stud. Juli 2012;49(7):775-83.

4. Drews T, Franck M, Radtke FM, Weiss $B$, Krampe $H$, Brockhaus WR, u. a. Postoperative delirium is an independent risk factor for posttraumatic stress disorder in the elderly patient: A prospective observational study. Eur J Anaesthesiol. März 2015;32(3):147-51.

5. Inouye SK, Marcantonio ER, Kosar CM, Tommet D, Schmitt EM, Travison TG, u. a. The short-term and long-term relationship between delirium and cognitive trajectory in older surgical patients. Alzheimers Dement. Juli 2016;12(7):766-75.

6. Lingehall HC, Smulter NS, Lindahl E, Lindkvist M, Engström KG, Gustafson YG, u. a. Preoperative Cognitive Performance and Postoperative Delirium Are Independently Associated With Future Dementia in Older People Who Have Undergone Cardiac Surgery: A Longitudinal Cohort Study*. Crit Care Med. August 2017;45(8):1295-303.

7. Maldonado JR. Delirium pathophysiology: An updated hypothesis of the etiology of acute brain failure. Int J Geriatr Psychiatry. November 2018;33(11):1428-57.

8. Hamilton GM, Wheeler K, Di Michele J, Lalu MM, Mclsaac DI. A Systematic Review and Meta-analysis Examining the Impact of Incident Postoperative Delirium on Mortality. Anesthesiology. 1. Juli 2017;127(1):78-88.

9. Milbrandt EB, Deppen S, Harrison PL, Shintani AK, Speroff T, Stiles RA, u. a. Costs associated with delirium in mechanically ventilated patients*: Crit Care Med. April 2004;32(4):955-62.

10. Siddiqi N, House AO, Holmes JD. Occurrence and outcome of delirium in medical in-patients: a systematic literature review. Age Ageing. 1. Juli 2006;35(4):350-64.

11. Übergewicht und Fettleibigkeit nach Ländern weltweit [Internet]. Statista. [zitiert 19. Mai 2021]. Verfügbar unter: https://de.statista.com/statistik/daten/studie/153908/umfrage/fettleibigkeit-untererwachsenen-in-oecd-laendern/

12. Mensink GBM, Schienkiewitz A, Haftenberger M, Lampert T, Ziese T, Scheidt-Nave C. Übergewicht und Adipositas in Deutschland: Ergebnisse der Studie zur Gesundheit Erwachsener in Deutschland (DEGS1). Bundesgesundheitsblatt - Gesundheitsforschung - Gesundheitsschutz. Mai 2013;56(56):786-94. 
13. Blüher M. Inflammation: zwischen Adipositas, Diabetes und Sport. Diabetol [Internet]. 28. Januar 2021 [zitiert 8. Februar 2021]; Verfügbar unter: http://link.springer.com/10.1007/s11428-021-00719-x

14. Dietrich, A. S3-Leitlinie: Chirurgie der Adipositas und metabolischer Erkrankungen AWMF. 2018.

15. Müller A, Olbert M, Heymann A, Zahn PK, Plaschke K, von Dossow V, u. a. Relevance of peripheral cholinesterase activity on postoperative delirium in adult surgical patients (CESARO): A prospective observational cohort study. Eur J Anaesthesiol. Februar 2019;36(2):114-22.

16. Saklad M. GRADING OF PATIENTS FOR SURGICAL PROCEDURES. Anesthesiology. 1. Mai 1941;2(3):281-4.

17. Nagappa M, Liao P, Wong J, Auckley D, Ramachandran SK, Memtsoudis S, u. a. Validation of the STOP-Bang Questionnaire as a Screening Tool for Obstructive Sleep Apnea among Different Populations: A Systematic Review and Meta-Analysis. Arias-Carrion O, Herausgeber. PLOS ONE. 14. Dezember 2015;10(12):e0143697.

18. Gaudreau J-D, Gagnon P, Harel F, Tremblay A, Roy M-A. Fast, Systematic, and Continuous Delirium Assessment in Hospitalized Patients: The Nursing Delirium Screening Scale. J Pain Symptom Manage. April 2005;29(4):368-75.

19. IBM Corp. BM SPSS Statistics for Windows. Armonk, NY: IBM; 2017.

20. Fritz CO, Morris PE, Richler JJ. Effect size estimates: Current use, calculations, and interpretation. J Exp Psychol Gen. 2012;141(1):2-18.

21. Radtke FM, Franck M, Hagemann L, Seeling M, Wernecke KD, Spies CD. Risk factors for inadequate emergence after anesthesia: emergence delirium and hypoactive emergence. Minerva Anestesiol. Juni 2010;76(6):394-403.

22. Fadayomi AB, Ibala R, Bilotta F, Westover MB, Akeju O. A Systematic Review and Meta-Analysis Examining the Impact of Sleep Disturbance on Postoperative Delirium: Crit Care Med. Dezember 2018;46(12):e1204-12.

23. Shah N, Roux F. The Relationship of Obesity and Obstructive Sleep Apnea. Clin Chest Med. September 2009;30(3):455-65.

24. Jehan S, Myers AK, Zizi F, Pandi-Perumal SR, Jean-Louis G, McFarlane SI. Obesity, obstructive sleep apnea and type 2 diabetes mellitus: Epidemiology and pathophysiologic insights. Sleep Med Disord Int J. 2018;2(3):52-8.

25. Sher Y, Mooney J, Dhillon G, Lee R, Maldonado JR. Delirium after lung transplantation: Association with recipient characteristics, hospital resource utilization, and mortality. Clin Transplant. Mai 2017;31(5):e12966.

26. Aronson D, Bartha P, Zinder O, Kerner A, Markiewicz W, Avizohar O, u. a. Obesity is the major determinant of elevated $\mathrm{C}$-reactive protein in subjects with the metabolic syndrome. Int $\mathrm{J}$ Obes. Mai 2004;28(5):674-9.

27. Visser M. Elevated C-Reactive Protein Levels in Overweight and Obese Adults. JAMA. 8. Dezember 1999;282(22):2131. 
28. Lam EWK, Chung F, Wong J. Sleep-Disordered Breathing, Postoperative Delirium, and Cognitive Impairment: Anesth Analg. Mai 2017;124(5):1626-35.

29. Feinkohl I, Winterer G, Pischon T. Obesity and post-operative cognitive dysfunction: a systematic review and meta-analysis: Obesity and Post-Operative Cognition. Diabetes Metab Res Rev. September 2016;32(6):643-51.

30. Feinkohl I, Lachmann G, Brockhaus W-R, Borchers F, Piper SK, Ottens T, u. a. Association of obesity, diabetes and hypertension with cognitive impairment in older age. Clin Epidemiol. Juli 2018;Volume 10:853-62.

31. Ranhoff AH, Rozzini R, Sabatini T, Cassinadri A, Boffelli S, Trabucchi M. Delirium in a Sub-Intensive Care Unit for the elderly: occurrence and risk factors. Aging Clin Exp Res. 2006;6.

32. Villalpando-Berumen JM, Pineda-Colorado AM, Palacios P, Reyes-Guerrero J, Villa AR, GutiérrezRobledo LM. Incidence of Delirium, Risk Factors, and Long-Term Survival of Elderly Patients Hospitalized in a Medical Specialty Teaching Hospital in Mexico City. Int Psychogeriatr. Dezember 2003;15(4):325-36.

33. Wakefield BJ. Risk for Acute Confusion on Hospital Admission. Clin Nurs Res. Mai 2002;20.

34. Inouye SK. Delirium in Hospitalized Older Patients: Recognition and Risk Factors. J Geriatr Psychiatry Neurol. Oktober 1998;11(3):118-25.

35. Tan MC, Felde A, Kuskowski M, Ward H, Kelly RF, Adabag AS, u. a. Incidence and Predictors of PostCardiotomy Delirium. Am J Geriatr Psychiatry. Juli 2008;16(7):575-83.

\section{Figures}




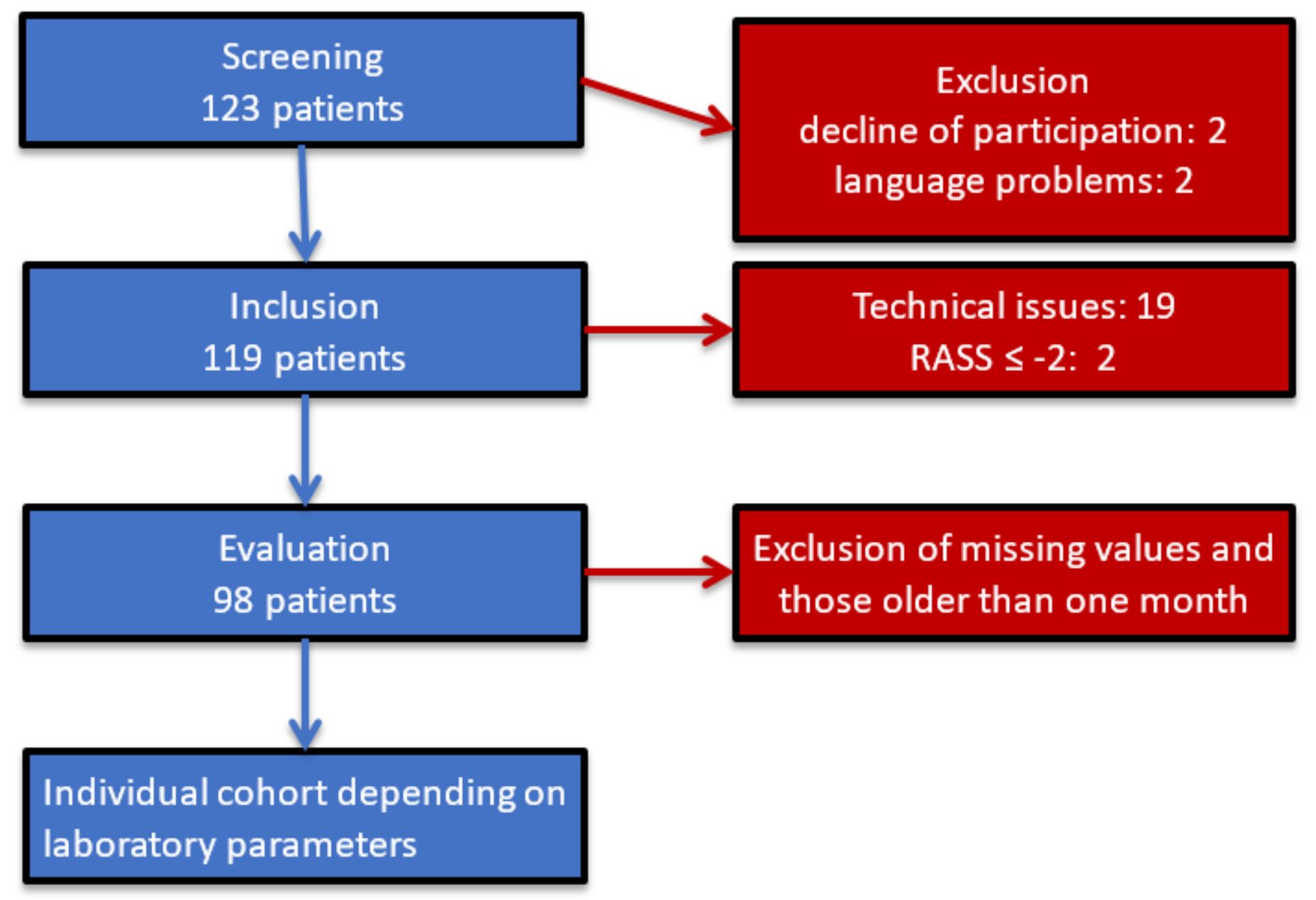

Figure 1

Flowchart 


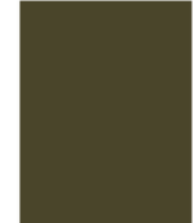

5

0

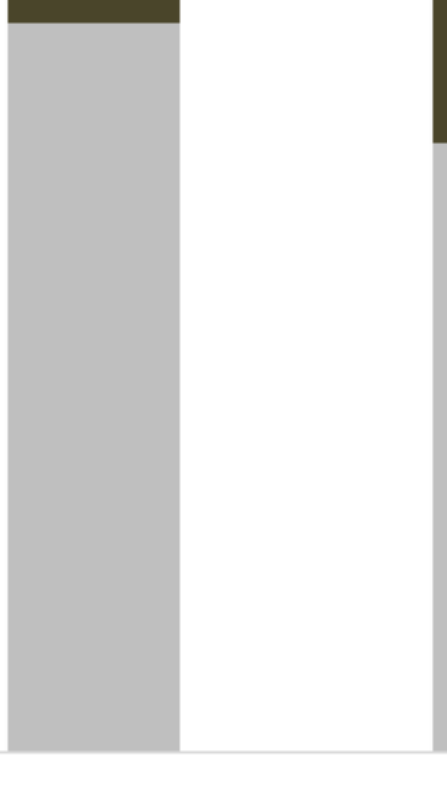

Stop-Bang $\geq 5$

- POD negative

OSAS

OSAS+CPAP

\section{Figure 2}

shows 3 groups differentiating in severity of OSAS. The first includes patients with an increased risk score (STOP-BANG $\geq 5$ ), the second includes patients who were diagnosed with OSAS (using polysomnography or polygraphy) and the third includes patients with OSAS requiring CPAP. 


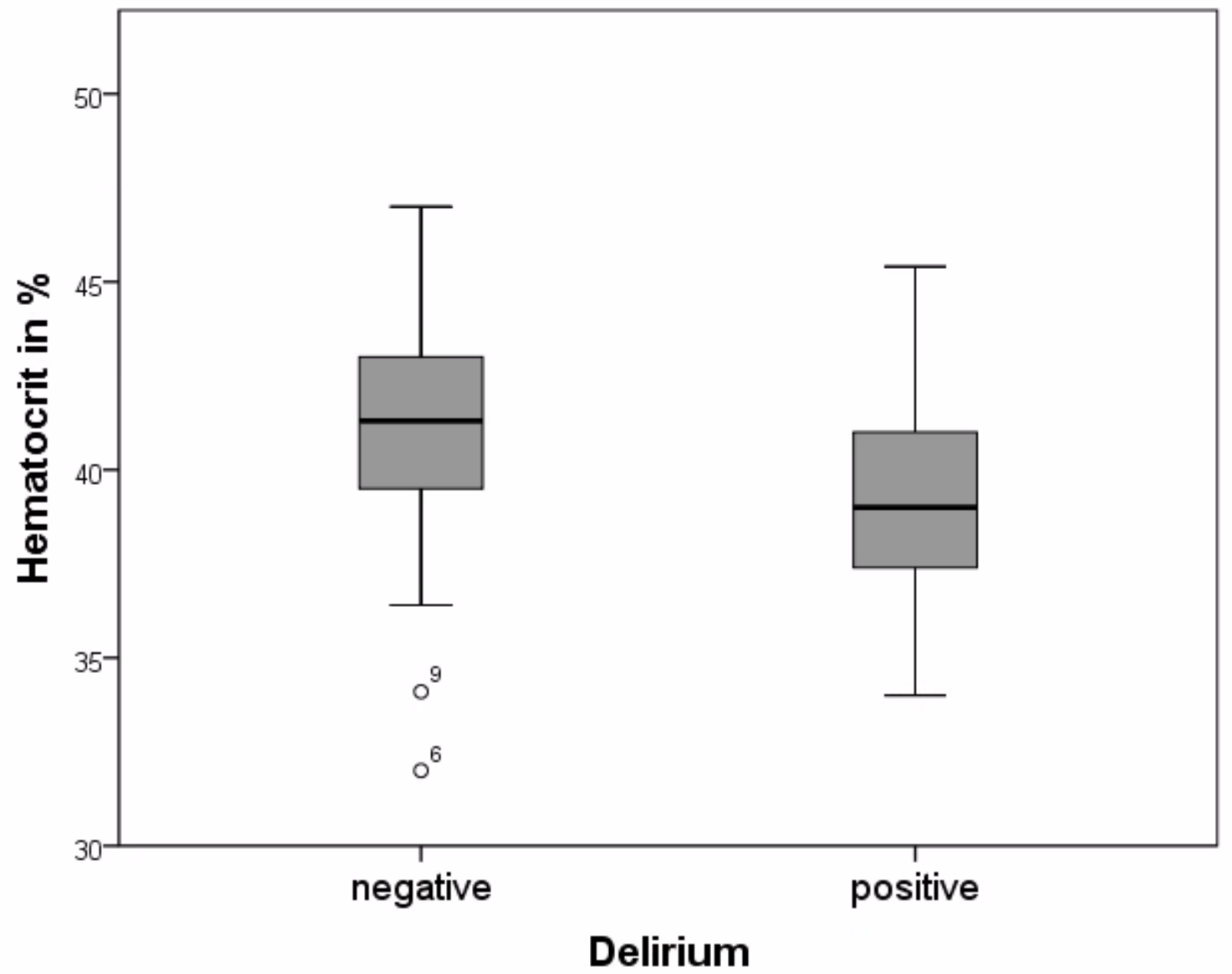

Figure 3

hematocrit concentration in patients with and without delirium. 


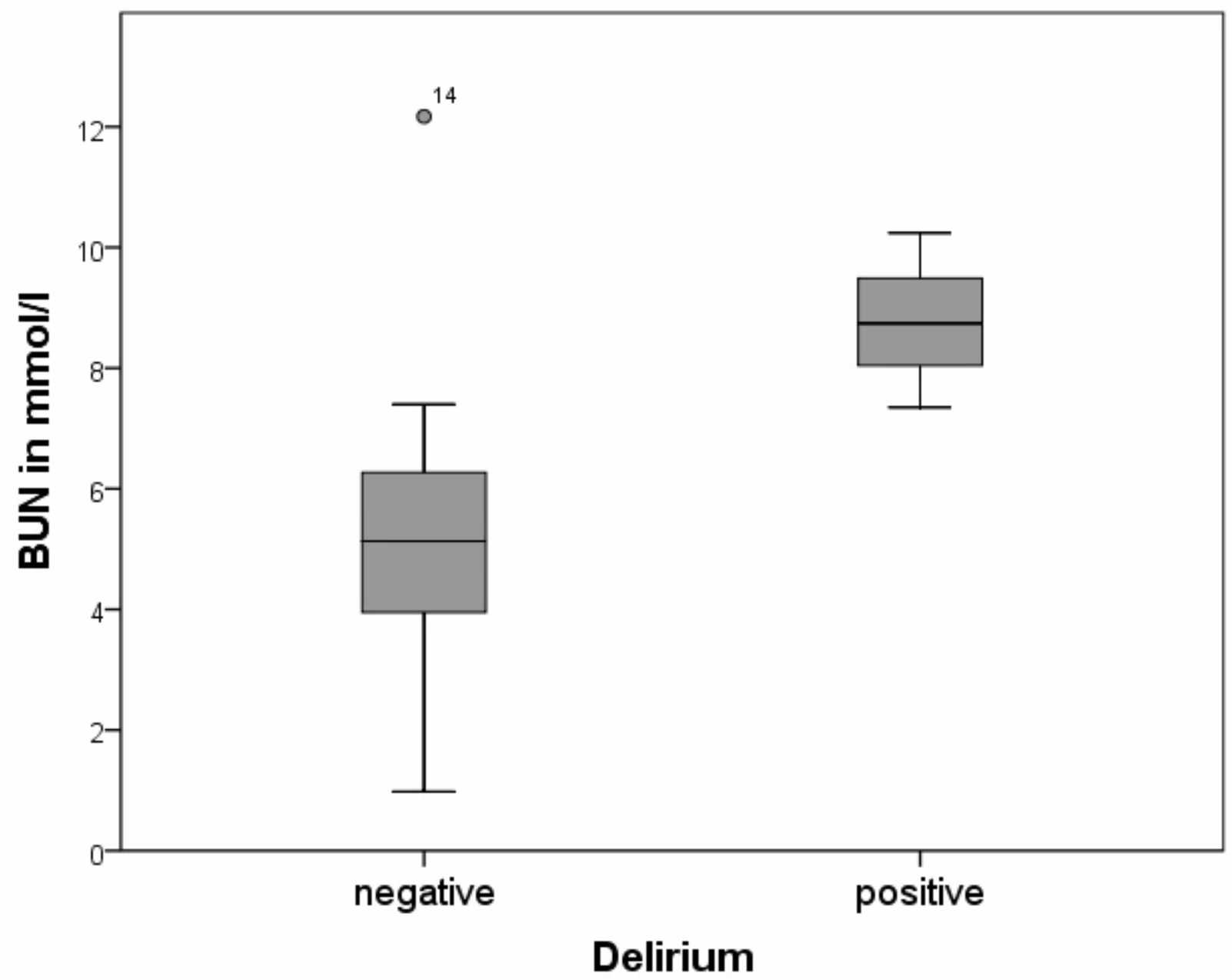

Figure 4

$\mathrm{BUN}$ in $\mathrm{mmol} / \mathrm{l}$ in patients with and without delirium. 